\title{
Cantos en tiempos de cuarentena
}

\author{
Marisol González Díaz
}

1963-2020

Habían transcurrido muchos días sin poder salir de mi casa. La ciudad entera estaba en cuarentena. ¿Qué puede hacer una cantante lírica en estas circunstancias?, me preguntaba. ¿Cómo aportar en este momento con mi oficio de cantora?

Los acontecimientos me habían sorprendido en medio de la organización de todas mis actividades y me sentía confundida en esta nueva dimensión donde el tiempo estaba dado solo por el reporte diario de la pandemia y una que otra clase de las que doy por Internet.

El reloj y el calendario no tenían ya sentido. Qué más daba si lunes o domingo o jueves, en todos hago lo mismo... Necesitaba una motivación grande que me devolviera a mi "quién soy" y el lugar que ocupo como parte de una sociedad.

Me senté al piano y comencé a cantar obras que hace tiempo tenía ganas de estudiar, pero faltaba algo más. Recordaba con nostalgia mis últimas presentaciones: el nervio antes de salir, la alegría al final de cada una, los ensayos, en fin...

Necesitaba ocupar mi lugar en medio de esta nueva y extraña realidad. Mi lugar de músico, de artista. Fue entonces que sin más, una tarde de marzo o abril, lunes o viernes, eso ya no importa, decidí abrir la ventana de mi balcón y cantar libremente una conocida aria de Verdi.

Solo sé que ya había oscurecido. Las luces de las ventanas y de los grandes edificios, que rodean el lugar donde vivo, daban un marco espléndido, como una gran platea. Por las ventanas se adivinaban las siluetas de quienes se asomaron a mirar, atraídos, supongo, por la música y la voz lejana que se imponía en la distancia rebotando en un sinfín de estructuras de cemento y hormigón. Así también resonaron los aplausos y las voces de los vecinos pidiendo una más. Decidí entonces repetir la experiencia cada noche a la misma hora.

1 Marisol González Díaz fue profesora de canto del Instituto de Música de la Pontificia Universidad Católica de Chile y de la Escuela Moderna de Música. Realizó conciertos durante la cuarentena de Santiago desde su ventana y dejó el plano terrenal en octubre del 2020. Que esta publicación póstuma sea en su memoria, siempre presente. 
Durante el día y a veces dependiendo de los acontecimientos positivos o tristes, planeaba mi gran función de la noche. El repertorio era importante. Debía estar en sintonía con los sucesos diarios.

Al pasar los días, decidí incluso vestirme para la ocasión, con mis trajes más lindos de concierto (los que me esperaban, merecían mi esfuerzo). Me maquillaba y preparaba para una gran función. Iluminaba mi balcón. Cantaba y al final, me despedía con una reverencia. Mi público, que eran mis vecinos, me esperaban cada noche en sus balcones y sus ventanas.

Recuerdo a un hombre mayor. Vivía dos pisos más abajo del mío en el edificio del frente. Siempre estaba listo a la hora señalada, con una copa en la mano y un cigarrillo. Al terminar mi presentación, alzaba su copa haciendo un brindis conmigo.

También recuerdo a una mujer joven que abría su cortina. Vivía justo en frente. Salía con quien imagino es su hija. La tomaba en brazos, me saludaba con la mano mientras yo cantaba y le hablaba al oído diciéndole no sé qué.

Había una familia. Ellos viven en un edificio un poco más lejos. Una pareja joven, dos niños, una señora mayor y un perro. Este último ladraba casi siempre. Sobre todo cuando cantaba mis notas más agudas.

Una noche, no salí a cantar, no recuerdo por qué. Al día siguiente, recibí un Whatsapp de unas vecinas del piso de arriba. Ellas son de La Serena y estudian acá en Santiago. La cuarentena las sorprendió aquí y no pudieron volver. Ellas se preocuparon y pensaron que tal vez yo había enfermado. Se habían quedado esperando en su mesita del balcón, con sus ya acostumbrados piscos sours, mi aparición en el gran escenario de cemento y barandas.

Alguien me comentó que el señor mayor del frente, se quedó mucho rato en su ventana mirando para ver si yo aparecía. Incluso lo vieron apagar su cigarrillo ya consumido, en un elegante cenicero de esos que presionas para que la colilla quede dentro. Eso me puso muy feliz y también un poco triste porque se deben haber sentido decepcionados o acaso tristes.

Imaginé que para algunos el momento aquel, era tal vez uno de los más esperados de su día y yo no debía jugar con eso. Esa noche traté de mostrar algo aún más especial y entonces busqué un acompañamiento instrumental en Internet y, junto a un parlante, canté "El vals de Musetta" de la conocida ópera de Giacomo Puccini, "La Boheme" ...

¡Gracias! ¡BRAVO! 


\section{Cantos en tiempos de cuarentena \\ Marisol González}

Aún estamos en cuarentena, ya llegó el invierno y no sé hasta cuándo cantaré. Hace frío en las ventanas y en nuestra paciencia. No importa, ya tengo mi motivo, el motivo de cualquier cantante, de cualquier artista.

Acompañar, alegrar, sentir, pensar, vivir.

Siento que cumplo mi misión y estoy tranquila por eso.

Un canto desde la ventana, desde la tierra hasta el cielo

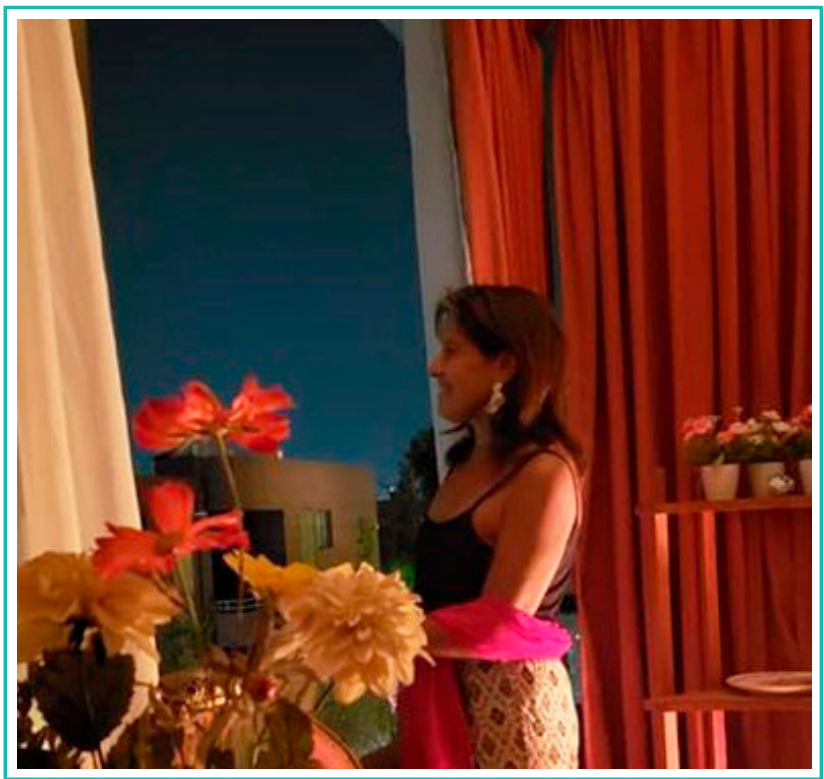

Cantos en tiempos de cuarentena 